\title{
A escrita no ensino fundamental II: uma análise linguística do erro ortográfico à luz dos modelos baseados no uso
}

\author{
Alcione de Oliveira Souza ${ }^{1}$ \\ Instituto Prominas de Educação e Tecnologia, Montes Claros, MG, Brasil
}

Resumo: Este artigo traz um recorte da Dissertação de Mestrado intitulada "Consciência Fonológica e Ortografia: uma intervenção na escrita de alunos do Ensino Fundamental II" (SOUZA, 2018), que investigou a eficácia de um plano de intervenção pedagógica aplicado a alunos, com dificuldades fono-ortográficas, matriculados no 6으 ano de uma escola pública de Montes Claros/MG. Este recorte apresentará a primeira etapa do estudo supracitado, referente ao diagnóstico e à caracterização dos principais erros ortográficos encontrados, que foram analisados à luz dos Modelos Baseados no Uso. Os resultados indicaram o apagamento do " $r$ " final em verbos no infinitivo como o tipo mais comum, causado pela transposição para a escrita da realização fonética referente à ausência do segmento sonoro / $r$ / em coda na sílaba final dos verbos infinitivos produzida pela comunidade linguística à qual os alunos pertencem.

Palavras-chave: Erros ortográficos; Modelos baseados no uso; Ensino fundamental II.

Title: The writing in elementary school II: a linguistic analysis of orthographic error according to usage-based models

Abstract: This article presents a segment of the Master's Dissertation entitled "Phonological Awareness and Spelling: An intervention in the writing of Elementary School II students" (SOUZA, 2018), which investigates the effectiveness of a pedagogical intervention plan applied to students who have phonological and orthographic difficulties, and who are enrolled in the 6th grade of a public school in Montes Claros/MG. What follows presents the first stage of the study above, referring to the diagnosis and characterization of the main spelling "errors" found, which were analyzed according to Usage-Based Models. The results indicate that the deletion of the final $-r$ in infinitive verbs is the most common type of error caused by the transposition of phonetic realization into writing concerning the absence of the sound segment / $r$ / at the end of the final syllable of infinitive verbs, produced by the linguistic community to which the students belong.

Keywords: Orthographic error; Usage-based models; Elementary school II.

\footnotetext{
${ }^{1}$ Mestra em Letras pela Universidade Estadual de Montes Claros (Unimontes). Docente no Instituto Prominas de Educação e Tecnologia. Orcid: https://orcid.org/0000 0000-0002-6766-3824

E-mail: alcionemoreno@yahoo.com.br
} 


\section{Introdução}

É comum professores dos anos finais do Ensino Fundamental (6으 ao 9으 ano) reclamarem das dificuldades apresentadas por seus alunos quanto ao uso da língua, principalmente em seu registro escrito. O que costuma comprometer, de forma decisiva, o processo de ensino e aprendizagem não só no estudo da língua portuguesa, mas em todas as outras disciplinas escolares, refletindo, inclusive, na vida cotidiana desses alunos para além da sala de aula.

Pensando nisso, e numa forma de auxiliar os professores no enfrentamento de tais dificuldades, apresenta-se, neste artigo, um recorte da pesquisa que resultou na dissertação "Consciência Fonológica e Ortografia: uma intervenção na escrita de alunos do ensino fundamental II", que investigou a influência de uma intervenção específica na escrita de alunos do ensino fundamental II, com defasagem idade/ano escolar e dificuldades fonoortográficas. Trata-se da primeira etapa do estudo, que objetivou diagnosticar os principais erros ortográficos cometidos por 3 alunos do 60 ano do Ensino Fundamental, matriculados na escola estadual do Centro Socioeducativo de Montes Claros/MG, em 2016, com idades entre 15 e 18 anos. O intuito, naquela fase, era identificar o tipo de "erro" ortográfico mais recorrente, para, posteriormente, analisá-lo à luz dos Modelos Baseados no Uso, a fim de possibilitar a elaboração de um Plano de Intervenção que, pelo menos, minimizasse o problema.

Sabe-se que o diagnóstico é um passo fundamental na busca pela solução de qualquer problema de aprendizagem. Contudo, as causas dos erros ortográficos, principalmente na escrita de alunos do ensino fundamental II, com defasagem idade/ano escolar, podem ser muito variadas; o que acaba desanimando a maioria dos professores, que, além de não apresentarem uma formação suficiente (ou adequada) para enfrentarem o problema, ainda têm de lidar com salas de aula superlotadas e alunos cada vez mais desinteressados.

Diante dessa realidade, acredita-se que a estratégia de identificar os tipos de erros ortográficos cometidos pelos alunos, selecionando os mais recorrentes para uma análise mais detalhada, pode facilitar o trabalho dos professores, na medida em que, segundo Oliveira (2005, p. 42), permite a separação dos problemas ortográficos conforme a sua natureza, auxiliando na elaboração de propostas realmente eficazes de intervenção pedagógica.

\section{Os Modelos Baseados no Uso}

Para uma análise mais detalhada da natureza do "erro" ortográfico, são sugeridos os Modelos Baseados no Uso, que consideram os aspectos cognitivos, sociointeracionais e 
culturais envolvidos no desenvolvimento da linguagem ao conceberem o significado como "uma construção mental, em um movimento contínuo de categorização e recategorização do mundo, a partir da interação de estruturas cognitivas e modelos compartilhados de crenças socioculturais" (FERRARI, 2014, p. 15). Ou seja, a atribuição de sentidos seria uma construção cognitiva humana através da qual o mundo é projetado numa representação mental da realidade pelo indivíduo.

Nessa perspectiva, Bybee (2016, p. 340) considera a língua como "uma atividade encorpada que ocorre em tempo real, em situações reais, através de sistemas cognitivos reais, que tem grande potencial para nos levar à explicação daquilo que percebemos como estrutura linguística". Evidencia-se, assim, um dos principais pressupostos dos Modelos Baseados no Uso (Modelo de Redes, Fonologia do Uso e Modelo de Exemplares): o conhecimento linguístico (ou "gramática mental") emerge e se estrutura a partir do uso que o indivíduo faz da sua língua em eventos reais de comunicação.

O Modelo de Redes, segundo Bybee (2007, p. 169-171), trata da organização da "gramática mental", que se dá a partir das conexões estabelecidas entre categorias linguísticas e não linguísticas, memorizadas durante o uso da língua, considerando os seguintes pressupostos:

a) os itens lexicais que formam o léxico possuem graus de força lexical, devido a sua frequência de ocorrência;

b) itens lexicais estão inter-relacionados por meio de redes de conexões lexicais entre traços semânticos ou fonológicos, idênticos ou similares, definindo a sua estrutura morfológica;

c) grupos de itens lexicais que possuem padrões fonológicos ou semânticos similares estão mutuamente reforçados e criam generalizações emergentes, descritas como esquemas ou padrões, cuja produtividade é uma consequência direta da frequência de tipo (BYBEE, 2007, p. 169-171).

A Fonologia de Uso, por sua vez, concebe o conhecimento gramatical como resultado da categorização e da organização das formas dos itens lexicais armazenados. O que, conforme Bybee (2001, p. 6-7), produz "generalizações e segmentações em vários graus de abstração e generalidade". Dessa forma, para a compreensão do processo, a autora postula:

a) a experiência afeta representação mental, ou seja, o uso de formas e padrões na produção ou percepção afeta sua representação na memória;

b) a representação mental de objetos linguísticos possui as mesmas propriedades que as representações mentais de outros objetos, ou seja, o cérebro opera da mesma maneira em diferentes domínios;

c) a categorização é baseada em identidade ou similaridade;

d) as generalizações sobre formas não estão separadas de sua representação armazenada, mas emergem diretamente delas. Ou seja, essas generalizações são elaboradas a partir das relações entre as formas, baseadas em similaridades fonética e/ou semântica;

e) a organização lexical produz generalizações e segmentações em vários graus de abstração e generalidade;

f) o conhecimento gramatical é um conhecimento procedimental (BYBEE, 2001, p. 6-7). 
Por fim, tem-se o Modelo de Exemplares, que, segundo Bybee (2016), complementa as teorias do Modelo de Redes e da Fonologia de Uso, ao determinar que a categorização e a organização dos itens lexicais armazenados configuram-se em "nuvens" (grupos) de exemplares (formas fonéticas produzidas ou ouvidas pelo falante e estabelecidas em sua memória) que se juntam a partir de suas similaridades, na forma e/ou no significado, e dos contextos de uso.

Sobre essa movimentação de exemplares, a autora destaca a influência da força lexical (que aproxima os exemplares semelhantes e afasta os diferentes) e da frequência de uso (número de vezes que um determinado item linguístico é usado) que pode afetar não só a forma fonética das palavras, como também a natureza da representação mental, já que, através do uso e da repetição, fortalecem-se na memória, modificando o conteúdo das nuvens de exemplares.

Cumpre apresentar, ainda, os tipos de conexão considerados na análise dos dados desta pesquisa, que se baseou na sugestão de graus de similaridade (total ou parcial) de Barbosa (2013, p. 126), a partir dos tipos de conexão propostos por Bybee (1985). Assim, propôs-se, como conexão fonológica total, a relação de similaridade completa na forma com significados gramaticais diferentes; como conexão fonológica parcial, a relação de similaridade parcial na forma - apenas em partes da representação - com significados gramaticais distintos; como conexão morfofonológica total, relação de identidade tanto na forma quanto no significado gramatical; conexão morfofonológica parcial, similaridade parcial na forma e identidade no significado gramatical, identidade na forma e similaridade parcial no significado gramatical, ou similaridade parcial na forma e no significado gramatical); e, por fim, como conexão morfológica, a relação de identidade no significado gramatical.

\section{A natureza dos erros ortográficos}

Com base na psicologia piagetiana, Ferreiro e Teberosky (1985, p. 275) apresentam a teoria dos níveis de leitura e de escrita como reflexo do desenvolvimento cognitivo do sujeito em interação com o objeto do conhecimento, num processo de apropriação do sistema alfabético a partir da perspectiva do aprendiz, isto é, de hipóteses construídas conforme a sua interação com o objeto "escrita".

Nessa perspectiva, vários autores (OLIVEIRA, 2005; BORTONI-RICARDO, 2006; SIMÕES, 2006; CAGLIARI, 2009; MOLLICA, 2016; entre outros) discutem a pressão que a oralidade exerce sobre a variação e a mudança linguística, ocasionando modificações nos padrões de uso, gerando consequências na escrita; e compartilham o entendimento de que o "erro" nem sempre representa uma falha que deve ser corrigida, mas um reflexo do trabalho cognitivo de hipotetização realizado pelo aluno, que, nesse momento, estaria analisando as 
possibilidades de representação da língua, ainda que usando, como base, o conhecimento da língua (oral) que já possui.

Tal processo de hipotetização configura-se como um exemplo de metalinguagem, que, conforme a literatura (BARRERA; MALUF, 2003; GOMBERT, 2003; GUIMARÃES, 2003; CAPOVILLA; CAPOVILLA, 2004; DINIZ, 2008), é um tipo de metacognição relacionada à linguagem, isto é, uma atividade consciente que pressupõe do sujeito uma atitude reflexiva diante dos objetos linguísticos e de sua manipulação. O que pressupõe a importância do desenvolvimento metalinguístico no trabalho com a ortografia, bem como da compreensão da natureza das hipóteses (estratégias) pensadas pelos aprendizes, a fim de classificar os erros cometidos, distinguindo aqueles que, de fato, servirão como subsídio para a construção do conhecimento.

Diversos trabalhos (OLIVEIRA; NASCIMENTO, 1990; OLIVEIRA, 2005; BORTONIRICARDO, 2005; ZORZI, 2007; CAGLIARI, 2009; SEARA et al.) discutem o erro ortográfico, apresentando diferentes tipos de categorizações a partir da ideia de sua sistematicidade e previsibilidade. Contudo, tomou-se por referência, nesta pesquisa, a classificação proposta por Oliveira (2005), por considerar suas explicações mais acessíveis (porque mais objetivas e didáticas) aos professores em geral (seja de Língua Portuguesa, com formação insuficiente em Linguística, e/ou de outras áreas do conhecimento) que se interessarem em utilizá-la.

Dessa forma, apresenta-se, a seguir, no Quadro 1, o esquema da proposta de Oliveira (2005), que categoriza os erros ortográficos com base na relação som/grafema estabelecida pelo aluno na elaboração de hipóteses sobre a construção da escrita, indicando as dificuldades mais importantes do ponto de vista da necessidade (e possibilidade) de intervenções pedagógicas realmente eficazes.

Quadro 1 - Categorias e subcategorias de erros ortográficos, segundo Oliveira (2005)

\begin{tabular}{|cl|}
\hline Categorias de erros ortográficos & \multicolumn{1}{c|}{ Subcategorias } \\
\hline Categoria 1 & A- Escrita pré-alfabética \\
(Dificuldades mais visíveis) & B-Troca de letra por semelhança de traçado \\
C-Troca de letra pela mudança de sons & \\
(Dificuldades mais importantes) & D-Dificuldade na compreensão das relações \\
& biunívocas entre os sons e os grafemas \\
& E-Dificuldade na concepção de convenções \\
& invariantes que controlam a representação \\
& de alguns sons \\
& F-Interferência das características estruturais \\
do dialeto do aluno na relação entre os sons & e os grafemas \\
& G-Transgressão de formas dicionarizadas \\
Categoria 3 & H-Dificuldade na escrita das sequências das \\
palavras \\
(Dificuldades que ultrapassam a relação & I-Hipercorreção \\
som/grafema) & J-Casos acidentais \\
\hline
\end{tabular}

Fonte: Souza (2018, p. 71). 
Para categorizar os erros, Oliveira (2005) analisa as possíveis hipóteses e/ou estratégias que os aprendizes utilizam na construção de representações gráficas da fala. Assim, de acordo com ele, o Grupo 1 refere-se às dificuldades referentes à própria natureza da escrita alfabética, sendo, por isso, mais perceptíveis na escrita dos alunos. São elas:

a) Escrita pré-alfabética: o aluno ainda estaria no início da aquisição da escrita, ou seja, ainda não teria passado da hipótese silábica para a alfabética. Por esse motivo, casos desse tipo costumam assustar pela aparência. Apesar disso, apresentam fácil solução através de estratégias que levem o aluno a mudar sua hipótese sobre a representação das estruturas sonoras (Ex.: "cledro" por "calendário", "olpiemu" por "o lápis é meu").

b) Troca de letra por semelhança de traçado: a semelhança visual entre algumas letras $(-p /-b,-m /-n,-p /-q)$ costuma confundir alguns alunos, que acabam traçando-as de forma inadequada (Ex.: "noda" por "moda"). A troca pode ocorrer também por distração dos estudantes (Ex.: “2, я").

c) Troca de letra pela mudança de sons: casos em que o aluno apresenta dificuldade em fazer distinções auditivas. Costuma acontecer durante algumas atividades de sala de aula, especialmente os ditados, já que os alunos tendem a repetir, de forma sussurrada, as palavras ditadas, comprometendo, assim, a sonoridade delas, incorrendo na troca de letras sonoras por suas correspondentes surdas (Ex.: "cheito" por "jeito", "cato" por "gato") $)^{2}$

O Grupo 2, por sua vez, refere-se às dificuldades mais importantes (incluindo o apagamento do " $r$ " final em verbos no infinitivo: caso mais recorrente na escrita dos alunos pesquisados, categorizada pelo autor como $2 \mathrm{~F}$ ):

a) Dificuldade na compreensão das relações biunívocas entre os sons e os grafemas: o aluno ainda não teria conseguido estabelecer as relações básicas entre alguns sons e alguns grafemas, como o fato de o som [f], por exemplo, ser representado graficamente apenas pela letra -f. Trata-se de um caso mais raro de ocorrer (Ex.: o aluno tem a intenção de escrever a palavra "bola" mas utiliza qualquer sequência de letras, como "cevu").

b) Dificuldade em conceber algumas convenções invariantes que controlam a representação de alguns sons: ocorre quando o aprendiz desconhece algumas regras invariantes (Ex.: o aluno escreve corretamente a palavra "gota", mas "gitara" em vez de "guitarra"). Observa-se o desconhecimento das regras invariantes para a escrita correta do som [g] diante do som [i], além do [r] entre vogais. Esta última referente à representação de dois fonemas por um mesmo grafema, conforme o contexto (Ex.:

\footnotetext{
${ }^{2} \mathrm{O}$ autor não aponta, mas outra explicação possível para esse tipo de troca seria a influência da variante falada pelos alunos na escrita. Não é o caso dos participantes deste estudo.
} 
grafema $-r$ representando o fonema $[\mathrm{h}]$ em início de palavras = "rato", ou representando o fonema [r] entre vogais = "cara"). Há, ainda, casos em que um mesmo fonema pode ser representado por dois grafemas (Ex.: fonema [h] representado por -rr entre vogais e nos demais contextos), além de vogais nasalizadas representadas por dígrafo (Ex.: "venda", limpo", "fim"). Em casos assim, Oliveira (2005) ressalta a necessidade de o professor incentivar o aluno a descobrir as regras responsáveis por essas grafias.

c) Interferência das características estruturais do dialeto do aluno na relação entre os sons e os grafemas: trata-se da influência da fala na escrita ocasionando erros ortográficos, seja por relações opacas ${ }^{3}$ (Ex.: "sou" ['sow], para "sol"; "fala" [fala'] para "falar"), seja em casos de neutralização (Ex.: "mezmo" ['mezmu] para "mesmo"), ou ainda em fenômenos de monotongação ou de ditongação (Ex.: "pego" [pe'go] para "pegou", "boxiadoura" [boksia'dowre] para "boxeadora").

d) Transgressão de formas dicionarizadas: trata-se do problema mais difícil de ser enfrentado, tanto pelo aluno quanto pelo professor, já que se refere às grafias de natureza totalmente arbitrárias, ou seja, não existem regras que ajudem no controle da escrita ou justificativas oriundas da influência da oralidade ou do dialeto do aprendiz. São casos, portanto, aprendidos individualmente e que requerem um trabalho de memorização muito grande, através de leituras e de consultas ao dicionário (Ex.: o aluno escreve "sinto", referindo-se ao utensílio "cinto", e viceversa). Nesse caso, o autor chama a atenção para a ineficácia do chamado "treino ortográfico", já que não promove o recurso ao significado e ao contexto de ocorrência da palavra ou das palavras em questão.

O Grupo 3, por fim, apresenta os problemas que ultrapassam a relação som e grafema, como os casos de ocorrências acidentais, ilustradas tanto pela supressão como pelo acréscimo de letras nas palavras:

a) Dificuldades na escrita das sequências das palavras: são os casos em que a forma como a palavra é dividida na fala não corresponde à divisão realizada na escrita (Ex.: "derrepente" por "de repente", "praquela" por "para aquela").

b) Hipercorreção: o caso mais comum desse tipo de desvio é a escrita das formas verbais na 3 a pessoa do passado com -I final, em vez de "u" (Ex.: "sail" e "abril", por "saiu" e "abriu"). Aqui, o autor salienta ser preciso que o professor promova o entendimento de que se trata de uma flexão verbal, isto é, uma marca de tempo e

\footnotetext{
${ }^{3}$ Entende-se por opaca a relação entre fonema e fone quando o fonema em questão admite mais de um fone (pronúncias diferentes). Assim, quando o fonema é pronunciado de um único modo (Ex.: $/ \mathrm{v} /=[\mathrm{v}])$, tem-se uma relação transparente (OLIVEIRA; NASCIMENTO, 1990, p. 40). Para Soares (2016, p. 288), são transparentes as ortografias que possuem consistência biunívoca nas correspondências fonema-grafema, e opacas, aquelas que apresentam inconsistência ou arbitrariedade nessas correspondências.
} 
pessoa que deve ser escrita sempre com - u no final, e nunca com -I, posto ser o verbo a única classe que pode ser conjugada.

c) Casos acidentais: como o próprio nome já prevê, trata-se de casos esporádicos, que, em si, não possuem a explicação de sua ocorrência (Ex.: "sofrinerto" para "sofrimento"). Assim, segundo o autor, podem decorrer, muitas vezes, da simples desatenção do aprendiz ao escrever.

\section{Materiais e métodos}

O universo desta pesquisa foi constituído por 3 alunos, do sexo masculino, com faixa etária entre 15 e 18 anos e defasagem idade/ano escolar, matriculados no sexto ano do ensino fundamental da Escola Estadual de Ensino Fundamental e Médio, em 2016, na cidade de Montes Claros-MG. Por se tratar de uma escola que funciona dentro de um Centro de Internação de Menores Infratores (Sistema Socioeducativo), os estudantes foram tratados, no texto, como informantes 1, 2 e 3 (seguindo as normas de segurança da Instituição, que proíbem a divulgação da identidade dos menores internados). A escolha dos participantes considerou as dificuldades fono-ortográficas apresentadas por eles, os perfis sociais semelhantes e a previsão de saída mais tardia do regime (devido à grande rotatividade de alunos na escola).

O informante 1 (18 anos) apresentava mais tempo fora da escola (6 anos), além de ser o único com histórico de repetência (repetiu uma vez o 4ㅇan ano do ensino fundamental). 0 Informante 2 (15 anos), por sua vez, permaneceu 4 anos afastado do ambiente escolar, enquanto o Informante 3 (17 anos) ficou 5 anos longe da escola. Todos interromperam os estudos quando cursavam o 60 ano do ensino fundamental.

A coleta de dados ${ }^{4}$ foi realizada através da observação participante e da aplicação de uma atividade escrita pela própria professora-pesquisadora, que, aproveitando a exibição do filme "Menina de ouro" ${ }^{5}$ (prevista como uma das ações de um projeto de prevenção ao suicídio em andamento na escola), pediu aos alunos que recontassem ${ }^{6}$, por escrito, o seu enredo. Essa atividade foi escolhida por envolver uma prática (exibição de filmes) que

\footnotetext{
${ }^{4}$ Os dados utilizados neste artigo fazem parte de uma pesquisa mais ampla, cuja entrada no Comitê de Ética da Universidade Estadual de Montes Claros se deu sob n. 59570116.2.0000.5146 e foi aprovado em 05/09/2016.

${ }^{5}$ Direção: Clint Eastwood. Produção: Warner Bros, Lakeshore Entertainment, Malpaso Productions, Albert S. Ruddy Productions, Epsilon Motion Pictures, Manaus, 2004, DVD.

${ }^{6}$ Acredita-se que o alto índice de casos com o fenômeno estudado ocorra por conta do tipo de texto (narrativo) escolhido para a obtenção de dados, visto que uma das características dessa tipologia textual seja a presença de muitos verbos, tanto na forma infinitiva quanto na forma flexionada.

${ }^{7}$ Conforme Bybee (2001, p. 4-6), o uso interfere na forma como os itens lexicais são representados na memória dos usuários, sendo duas as espécies de frequência de uso possíveis, a saber: frequência de tipo (type frequency) - número de elementos ou tipos linguísticos diferentes que compartilham um padrão específico em um corpus - e frequência de ocorrência (token frequency) - número de vezes que um determinado elemento ou tipo linguístico (geralmente uma palavra) aparece em um corpus (BYBEE, 2001, p. 10-12, tradução minha).
} 
costuma agradar aos alunos, deixando-os, assim, mais à vontade para que realizassem o reconto da forma mais espontânea possível.

Dessa forma, as dificuldades ortográficas encontradas nos textos produzidos pelos alunos foram analisadas segundo a categorização proposta por Oliveira (2005), sendo também quantificadas em relação à sua frequência de tipo e frequência de ocorrência ${ }^{7}$, no sentido de evidenciar o tipo de maior recorrência, além da sua natureza.

\section{Resultados}

De acordo com os dados coletados, foi possível constatar que as dificuldades ortográficas mais observadas referem-se à interferência das características estruturais do dialeto da comunidade à qual os alunos pertencem, transpondo para a escrita alguns fenômenos fonológicos como, por exemplo, a monotongação ("começo" [kome'so], para "começou") a ditongação ("mais" ['majs], para "mas"), o apagamento de sílaba átona inteira ("tava" ['tave], para "estava") e o apagamento de "r" final em verbos no infinitivo ("luta" [lu'ta], para "lutar"), sendo este último o mais comum.

O Quadro 2, a seguir, ilustra os casos de frequência de tipo encontrados na escrita dos alunos (numerados de 1 a 3 ).

Quadro 2 - Casos de frequência de tipo por categoria de erros ortográficos e informante

\begin{tabular}{|l|c|c|c|}
\hline \multicolumn{2}{|c|}{ Categorias de erros ortográficos } & \multicolumn{2}{c|}{ Casos de frequência de tipo de erros ortográficos por } \\
informante
\end{tabular}




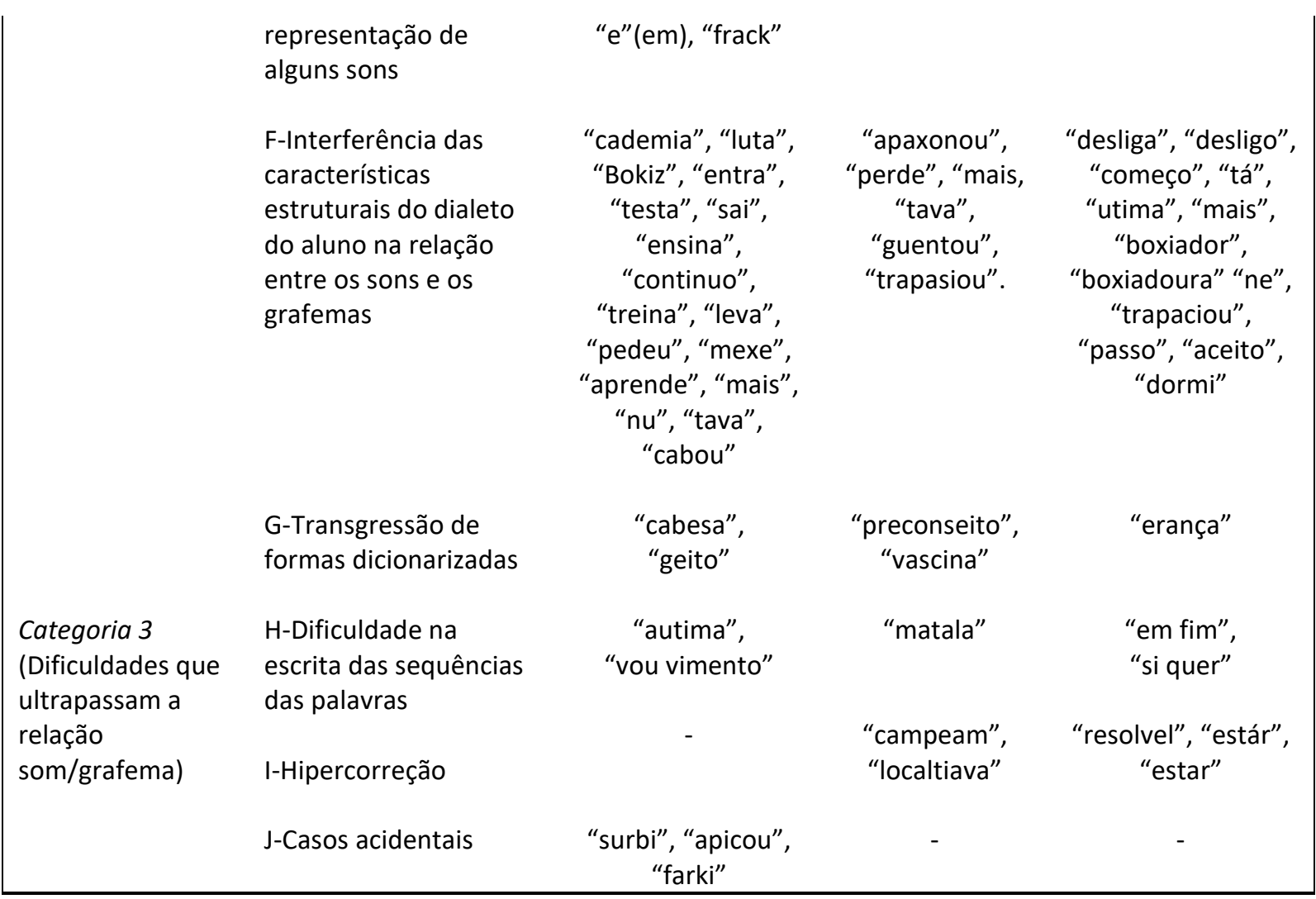

Fonte: Souza (2018, p. 85).

Conforme as informações do Quadro 2, todos os alunos apresentaram dificuldades em conceber convenções invariantes (subcategoria 2E), como, por exemplo, a exigência da letra " $m$ " antes das letras " $p$ " e " $b$ " (Ex.: "tenpo" para "tempo"), além das relações plurívocas existentes entre alguns sons e seus grafemas, como, por exemplo, o som /s/ e seus possíveis grafemas ou sequências correspondentes "s", "sc" (Ex.: "vascina" [va'sine] para "vacina").

Apresentaram também dificuldades fono-ortográficas relacionadas a características estruturais de seus dialetos (2F), escrevendo conforme falam (Ex.: ausência de representação gráfica para fonemas não pronunciados em coda silábica ou sílabas átonas (Ex.: "utima"

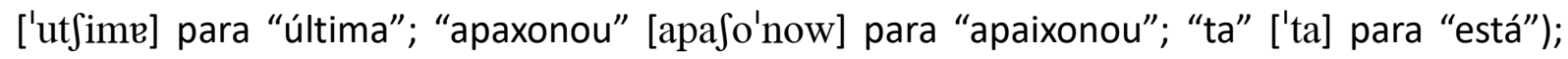
além da escrita de sequências sonoras no mesmo ritmo que são pronunciadas $(3 \mathrm{H})$, incorrendo tanto na transcrição do fenômeno fonológico da segmentação (Ex.: "si quer" ['si 'ke] para "sequer") quanto no da juntura (Ex.: "matala" [ma'tale] para "matá-la"). Oliveira (2005) destaca tais erros como os mais importantes cometidos pelos alunos, posto se tratarem de dificuldades que necessitam de intervenções mais pontuais e mediadas pelo professor.

Por outro lado, nenhum dos alunos apresentou dificuldades referentes à escrita préalfabética, demonstrando boa compreensão sobre a escrita silábica (representação de grupos de sons) e escrita alfabética (representação de sons individuais), o que sugere que 
eles já teriam avançado da hipótese silábica para a alfabética. Quanto à subcategoria 1B, referente à troca de letras por semelhança de traçado, apareceram apenas dois casos ("cento" para "certo" e "sofrinerto" para "sofrimento"), indicando provável confusão dos alunos (Informantes 1 e 2 ) entre as grafias das letras -r/-n e -m/-n, respectivamente.

As subcategorias $1 \mathrm{C}$ (troca de letras por mudança de sons) e 2D (dificuldade na compreensão das relações biunívocas entre os sons e os grafemas) foram representadas por um caso cada: "quatava", em vez de "aguentava" (1C) e "cosiquenha", no lugar de "conseguia" (2D). Ambas ocorrências foram cometidas por apenas um dos alunos (Informante 1), demonstrando que talvez ele ainda não reconheça diferenças quanto à sonorização de alguns fonemas (/g/ e /k/, etc.) ou não perceba relações mínimas de correspondência entre alguns sons e alguns grafemas ( $-f=/ f /$, etc. $)$.

Oliveira (2005, p. 43-44) atenta para a seriedade de erros como os referentes às subcategorias $1 \mathrm{C}$ e 2D, visto que podem impossibilitar o aprendizado, exigindo outros tipos de intervenção, antes da pedagógica, como, por exemplo, as de caráter percepto-cognitiva. Já em relação às dificuldades que representaram a subcategoria 1B, o autor afirma que, por se tratar de problemas naturalmente temporários, são fáceis de serem resolvidos, bastando um treinamento sobre o traçado das letras em questão.

Tabela 1 - Categorização dos erros ortográficos e sua frequência de ocorrência por informante

\begin{tabular}{|c|c|c|c|c|c|c|}
\hline \multicolumn{2}{|c|}{ Categorias de erros ortográficos } & \multicolumn{3}{|c|}{$\begin{array}{l}\text { Frequência de ocorrência dos } \\
\text { erros ortográficos por informante }\end{array}$} & \multirow{2}{*}{ Total } & \multirow{2}{*}{$\%$} \\
\hline & Subcategorias & 1 & 2 & 3 & & \\
\hline \multirow{3}{*}{$\begin{array}{c}\text { Categoria } 1 \text { (Dificuldades } \\
\text { mais visíveis) }\end{array}$} & A - Escrita pré-alfabética & - & - & - & - & - \\
\hline & $\begin{array}{l}\text { B -Troca de letra por } \\
\text { semelhança de traçado }\end{array}$ & 2 & 1 & - & 3 & 3,45 \\
\hline & $\begin{array}{l}\text { C -Troca de letra pela mudança } \\
\text { de sons }\end{array}$ & 1 & - & - & 1 & 1,15 \\
\hline \multirow[t]{4}{*}{$\begin{array}{l}\text { Categoria } 2 \text { (Dificuldades } \\
\text { mais importantes) }\end{array}$} & $\begin{array}{l}\text { D - Dificuldade na compreensão } \\
\text { das relações biunívocas entre } \\
\text { sons e grafemas }\end{array}$ & 1 & - & - & 1 & 1,15 \\
\hline & $\begin{array}{l}\text { E - Dificuldade na concepção de } \\
\text { convenções invariantes que } \\
\text { controlam a representação de } \\
\text { alguns sons }\end{array}$ & 10 & 3 & 1 & 14 & 16,08 \\
\hline & $\begin{array}{l}\text { F- Interferência das } \\
\text { características estruturais do } \\
\text { dialeto do aluno na relação } \\
\text { entre os sons e os grafemas }\end{array}$ & 28 & 6 & 15 & 49 & 56,32 \\
\hline & $\begin{array}{l}\text { G -Transgressão de formas } \\
\text { dicionarizadas }\end{array}$ & 2 & 2 & 1 & 5 & 5,75 \\
\hline Categoria 3 (Dificuldades & H - Dificuldade na escrita das & 2 & 1 & 2 & 5 & 5,75 \\
\hline
\end{tabular}




\begin{tabular}{llcccc}
\hline $\begin{array}{c}\text { que ultrapassam a } \\
\text { relação som/grafema) }\end{array}$ & sequências das palavras & & & & \\
& I- Hipercorreção & - & 2 & 4 & 6,90 \\
& J - Casos acidentais & 3 & - & - & 3,45 \\
& Total & 49 & 15 & 23 & 87 \\
\hline
\end{tabular}

Fonte: Souza (2018, p. 88).

Por sua vez, as subcategorias 3I (hipercorreção) (Ex.: "estár" em vez de "está") e 3J (casos acidentais) (Ex.: "apicou" no lugar de "aplicou") foram representadas de forma aleatória nos textos dos alunos, corroborando, assim, a afirmação de Oliveira (2005, p. 46) quanto ao caráter de aleatoriedade desse tipo de "erro".

Quantificando os erros ilustrados acima, segue a Tabela 1, que apresenta a frequência de ocorrência por subcategoria e informante.

A Tabela 1 demonstrou que a subcategoria de erros mais frequente nos textos dos alunos foi a $2 \mathrm{~F}$, referente à interferência das características estruturais do dialeto dos alunos na relação entre os sons e os grafemas, totalizando 49 casos $(56,32 \%)$. O que representa mais da metade do total de erros encontrados e revela a dificuldade que eles tinham em conceber os limites existentes entre as modalidades oral e escrita da língua.

Em segundo lugar, com 14 casos $(16,08 \%)$, aparece a subcategoria $2 E$, relacionada às dificuldades na concepção de convenções invariantes que controlam a representação de alguns sons; seguida pelos casos de hipercorreção (3I), com 6 casos (6,9\%), considerando casos ilustrativos desse fenômeno as palavras: "campeam", em que o aluno indicou a nasalização do -a com a letra -m em vez de utilizar o "til"; "estár" e "estar", em que a sílaba tônica foi reforçada ora pelo acento agudo aliado ao -r ("estár") ora pela presença da letra -r sem o acento agudo ("estar"), quando deveria apresentar somente o acento agudo ("está") por se tratar de verbo na 3 a pessoa do singular, no presente do indicativo. Observou-se, ainda, a palavra "resolvel", em que o aluno troca o - $u$ do verbo, na forma de 3 a pessoa do singular no passado, por -1 .

Segundo Oliveira (2005, p. 46-47), casos como o do registro do -l em vez do -u no final de verbos na 3 a pessoa do passado são os mais comuns de hipercorreção e de fácil correção, bastando o professor criar "situações que levam os alunos a entenderem que se trata de uma flexão verbal, isto é, uma marca de tempo e pessoa, que sempre é grafada com 'u' no final, nunca com 'l'”.

Em quarto lugar, aparecem as subcategorias 2G (transgressão de formas dicionarizadas) e $3 \mathrm{H}$ (dificuldade na escrita das sequências das palavras), com 5 casos $(5,74 \%)$ cada uma. Segundo Oliveira $(2005$, p. 45$)$, tratam-se de situações que exigem um trabalho individualizado e de memorização, já que os casos devem ser "aprendidos um a um, e somente a consulta ao dicionário ou a familiaridade da palavra podem resolver a questão da grafia" (no caso da subcategoria 2G). Além disso, demonstram um desenvolvimento 
insuficiente da consciência fonológica dos alunos nos anos iniciais quanto ao limite das palavras (no caso da subcategoria $3 \mathrm{H}$ ).

Assim, como exemplos da subcategoria 2G, foram registrados casos em que os alunos demonstraram ignorar algumas relações plurívocas do fonema /s/ com as letras -ç, -sc e -s ("cabesa" [ka'bese] para "cabeça"; "vascina" [va'sine] para "vacina"; e "preconseito" [prekõ'sejtu] para "preconceito"); e do fonema /3/ com as letras -j e -g ("geito" ['zejtu] para "jeito"); além do caso de não registro do grafema -h, como em "erança" (para "herança"). Como ilustração da subcategoria $3 \mathrm{H}$, houve o registro de casos tanto de juntura ("matala" [ma'tale] para "matá-la"), quanto de segmentação ("em fim" [ 'ẽj 'fĩ] para "enfim").

Por sua vez, os casos referentes à troca de letras por semelhança de traçado (subcategoria 1B) e os casos acidentais (3J), apresentando erros de origem desconhecida, ocuparam o quinto lugar, com 3 registros cada (3,45\%). Considerou-se como casos acidentais as palavras "surbi" (em vez de "subir") e "apicou" (no lugar de "aplicou"), que ratificam Oliveira (2005) quando o autor apresenta tais fenômenos como problemas de difícil solução, por não permitirem previsão de ocorrência ou pistas de sua natureza.

Por fim, aparecem representadas, com apenas 1 caso cada (1,15\%), as subcategorias 1C (troca de letras por mudança de sons), com o registro de "quatava", em vez de "aguentava"; e 2D (dificuldade na compreensão das relações biunívocas entre os sons e os grafemas), com a presença do item "cosiquenha", no lugar da palavra "conseguia".

A Tabela 2, a seguir, distribui os erros ortográficos encontrados nas produções dos alunos por frequências de tipo e de ocorrência, demonstrando a porcentagem das ocorrências em relação ao total de casos observados por aluno.

Tabela 2 - Distribuição dos erros ortográficos em frequências de tipo e de ocorrência por informante

\begin{tabular}{c|c|c|c|c}
\hline Informante & $\begin{array}{c}\text { Frequência de } \\
\text { tipo }\end{array}$ & $\%$ & $\begin{array}{c}\text { Frequência de } \\
\text { ocorrência }\end{array}$ & $\%$ \\
\hline 1 & 34 & 50,75 & 49 & 56,32 \\
2 & 13 & 19,40 & 15 & 17,24 \\
3 & 20 & 29,85 & 23 & 26,44 \\
Total & 67 & 100 & 87 & 100 \\
\hline
\end{tabular}

Fonte: Souza (2018, p. 90).

Analisando a Tabela 2, foi possível perceber que o informante 1 foi o que mais apresentou dificuldades de escrita, com 34 frequências de tipo de erros ortográficos, dos 67 catalogados $(50,75 \%)$, tendo repetido alguns desses tipos, incorrendo em 49 frequências de ocorrência (56,32\%). Em seguida, aparece o informante 3, com 20 frequências de tipo de erros ortográficos $(29,85 \%)$, repetindo 3 , totalizando 23 frequências de ocorrência $(26,44 \%)$; e, por fim, o informante 2, que, apresentando baixa frequência, registrou 13 frequências de 
tipo de erros ortográficos (19,40\%) e 15 frequências de ocorrência $(17,24 \%)$.

Acredita-se que a alta frequência de erros ortográficos apresentada pelo informante 1 deva-se ao seu afastamento da escola por 6 anos, após ter concluído o quinto ano do ensino fundamental, tendo ainda repetido uma vez o quarto ano (2008-2009). Somente em 2016, quando foi internado no Centro Socioeducativo de Montes Claros, é que ele voltou a frequentar efetivamente a sala de aula.

Quanto à baixa frequência de erros ortográficos do informante 2, não há evidências em seu perfil social que expliquem o fato de ele não ter apresentado a mesma média de erros do informante 3 , considerando a semelhança de seus perfis.

A fim de detalhar ainda mais a análise quanti-qualitativa realizada, segue a Tabela 3 , com as porcentagens das frequências de tipo e de ocorrências por fonte (princípio gerador) de erro, revelando a natureza dos tipos encontrados.

Tabela 3 - Total de erros ortográficos em frequências de tipo e de ocorrência por subcategoria e seus tipos

\begin{tabular}{|c|c|c|c|c|c|c|}
\hline \multicolumn{2}{|c|}{$\begin{array}{l}\text { Categorias de erros } \\
\text { ortográficos }\end{array}$} & \multicolumn{5}{|c|}{ Total de erros ortográficos em frequência de tipo e de ocorrência } \\
\hline & $\begin{array}{l}\text { Subcate- } \\
\text { gorias }\end{array}$ & Tipos de erro & $\begin{array}{l}\text { Freq. } \\
\text { tipo }\end{array}$ & $\begin{array}{c}\text { Total } \\
(\%)\end{array}$ & $\begin{array}{l}\text { Freq. } \\
\text { ocor. }\end{array}$ & $\begin{array}{c}\text { Total } \\
\text { (\%) }\end{array}$ \\
\hline \multirow[t]{6}{*}{ Categoria 1} & $\mathrm{~A}$ & - & 0 & 0 & 0 & 0 \\
\hline & B & $\begin{array}{l}\text { semelhança de traçado } \\
(-m /-n,-r /-n)\end{array}$ & 2 & 2,99 & 3 & 3,45 \\
\hline & & subtotal & 2 & 2,99 & 3 & 3,45 \\
\hline & & troca de letra pela mudança de som: & 1 & 1,49 & 1 & 1,15 \\
\hline & $\mathrm{C}$ & $/ \mathrm{g} / \mathrm{e} / \mathrm{k} /$ & & & & \\
\hline & & subtotal & 1 & 1,49 & 1 & 1,15 \\
\hline \multirow[t]{16}{*}{ Categoria 2} & $\mathrm{D}$ & $\begin{array}{l}\text { dificuldade na compreensão das relações biunívocas } \\
\text { entre sons e grafemas }\end{array}$ & 1 & 1,49 & 1 & 1,15 \\
\hline & & subtotal & 1 & 1,49 & 1 & 1,15 \\
\hline & $\mathrm{E}$ & $\begin{array}{l}\text { vogais nasalizadas em dígrafos no interior das } \\
\text { palavras }\end{array}$ & 6 & 8,95 & 8 & 9,18 \\
\hline & & uso das letras $-m$ e $-n$ antes de $-p$ ou $-b$ & 2 & 2,99 & 4 & 4,60 \\
\hline & & grafema - $r$ entre vogais & 1 & 1,49 & 2 & 2,30 \\
\hline & & subtotal & 9 & 13,43 & 14 & 16,08 \\
\hline & $\mathrm{F}$ & apagamento de - $r$ final em verbos no infinitivo & 11 & 16,42 & 16 & 18,39 \\
\hline & & neutralização & 5 & 7,46 & 6 & 6,90 \\
\hline & & monotongação & 6 & 8,95 & 6 & 6,90 \\
\hline & & apagamento de sílaba átona & 6 & 8,95 & 9 & 10,34 \\
\hline & & ditongação & 4 & 5,97 & 6 & 6,90 \\
\hline & & força do padrão CV & 2 & 2,99 & 3 & 3,45 \\
\hline & & apagamento de coda & 2 & 2,99 & 3 & 3,45 \\
\hline & & subtotal & 36 & 53,73 & 49 & 56,32 \\
\hline & G & relações plurívocas do fonema /s/ & 3 & 4,48 & 3 & 3,45 \\
\hline & & relações plurívocas do fonema /3/ & 1 & 1,49 & 1 & 1,15 \\
\hline
\end{tabular}




\begin{tabular}{|c|c|c|c|c|c|c|c|}
\hline & & grafema -h & & 1 & 1,49 & 1 & 1,15 \\
\hline & & & subtotal & 5 & 7,46 & 5 & 5,75 \\
\hline \multirow[t]{8}{*}{ Categoria 3} & $\mathrm{H}$ & juntura & & 2 & 2,99 & 2 & 2,30 \\
\hline & & segmentação & & 3 & 4,48 & 3 & 3,45 \\
\hline & & & subtotal & 5 & 7,47 & 5 & 5,75 \\
\hline & 1 & hipercorreção & & 5 & 7,46 & 6 & 6,90 \\
\hline & & & subtotal & 5 & 7,46 & 6 & 6,90 \\
\hline & J & casos acidentais & & 3 & 4,48 & 3 & 3,45 \\
\hline & & & subtotal & 3 & 4,48 & 3 & 3,45 \\
\hline & & & Total & 67 & 100 & 87 & 100 \\
\hline
\end{tabular}

Fonte: Souza (2018, p. 92).

Além de confirmar a subcategoria $2 \mathrm{~F}$ (interferência do dialeto do aluno na relação som/grafema) como a mais recorrente entre os informantes, com 36 frequências de tipo (53,73\%) e 49 frequências de ocorrência (56,32\%) de erros ortográficos no corpus, a Tabela 3 mostra ainda a frequência de tipo e a frequência de ocorrência em relação aos tipos dos erros observados nessa subcategoria.

Assim, o apagamento de " $r$ " final em infinitivo aparece com 11 frequências de tipo (16,42\%) e 16 de ocorrência (18,39\%) (Ex.:"fala" [fa'la] para "falar"), chegando a quase 1/3 dos casos referentes a esta subcategoria; a neutralização, com 5 frequências de tipo (7,47\%) e 6 de ocorrência (6,9\%) (Ex.: "nu" ['nu] para "no"); a monotongação, com 6 de tipo (8,95\%) e 6 de ocorrência (6,9\%) (Ex.: "pego" [pe'go] para "pegou"); o apagamento de sílaba átona inteira, com 6 (8,95\%) e 9 (10,34\%) (Ex.: "tava" ['tave], para "estava”); ditongação, 4 (5,97\%) e 6 (6,9\%) (Ex.: "mais" ['majs], para "mas"); reiteração da força do padrão CV, 2 (2,99\%) e 3 (3,45\%) (Ex.: "Fracki" ['frãki], para "Frank") e o apagamento de coda, com 2 (2,99\%) e 3 (3,45\%) (Ex.: "utima" ['utfime] para "última").

Em seguida, foram apresentadas, com 9 frequências de tipo $(13,43 \%)$, e 14 frequências de ocorrência $(16,08 \%)$, os tipos dos erros relacionados à subcategoria $2 E$ (referente à dificuldade na concepção de convenções invariantes que controlam a representação de alguns sons), a saber: ocorrências referentes às vogais nasalizadas representadas por dígrafos no interior das palavras, com 6 (8,95\%) e 8 (9,18\%) (Ex.: "pacada" [pã'kade] para "pancada"), além da convenção invariante de uso das letras -m e -n antes de -p ou -b, com 2 (2,99\%) e 4 (4,6\%) (Ex.: "tenpo" ['tẽpu] para "tempo"), e registro do grafema -r no contexto entre vogais, com $1(1,49 \%)$ e 2 (2,99\%) (Ex.: "moredo" [mo'hẽnu] para "morrendo"). Vale salientar que essas grafias, registradas pelos alunos, não correspondem à variante linguística falada por eles, como se pode perceber pelas transcrições que as acompanham.

A subcategoria $2 \mathrm{G}$ (transgressões de formas dicionarizadas), por sua vez, foi ilustrada com 5 frequências de tipo e 5 frequências de ocorrência (7,46\% e 5,75\%, respectivamente), 
contemplando as relações plurívocas dos fonemas /s/ e /3/ (Ex.: "cabesa" [ka'bese] em vez de "cabeça"; "geito" ['zejtu] para "jeito"), além do não registro do grafema -h (Ex.: "erança" no lugar de "herança"). E com 5 frequências de tipo e 5 frequências de ocorrência (7,46\% e $5,75 \%$, respectivamente) aparecem a subcategoria $3 \mathrm{H}$ (dificuldades na escrita das sequências das palavras) (Ex.: "matala" [ma'tale] para "matá-la"; "em fim" [ 'ẽj 'fĩ] para "enfim") e a subcategoria 3J (casos acidentais) (Ex.: "apicou" para "aplicou"). Além da subcategoria 3I (hipercorreção) aparece com 5 frequências de tipo $(7,46 \%)$ e 6 frequências de ocorrência (6,90\%) (Ex.: "estár" para "está").

Por fim, a Tabela 3 mostra a subcategoria 1B, relativa à troca de letras por semelhança de traçado, contemplando, especificamente, as letras -m/-n, com 1 frequência de tipo e 1 frequência de ocorrência (1,49\% e 1,15\%, respectivamente) (Ex.: "sofrinerto" para "sofrimento") e -r/-n, com 1 frequência de tipo e 2 de ocorrência (2,30\%) (Ex.: "cento" para "certo").

\section{Discussão}

Os resultados descritos acima evidenciaram que, embora os alunos pesquisados tivessem avançado da hipótese silábica para a alfabética, ainda se encontravam em estágio inicial de aprendizagem da ortografia, já que seus textos apresentaram problemas relacionados à interferência da oralidade na escrita. Este fato pode ser explicado pela baixa escolaridade dos indivíduos causada pelo desinteresse pelos estudos, além da evasão escolar, visto que eles se encontravam fora da escola por vários anos antes de serem apreendidos e encaminhados ao Centro de Internação, onde uma das condições para o fim da medida socioeducativa é a frequência às aulas.

Diversos estudos (ZORZI; CIASCA, 2008; JOLY et al., 2009; ROSA et al., 2012; TENÓRIO; ÁVILA, 2012, entre outros) já comprovaram a influência da escolaridade no processo de aquisição da escrita ortográfica, principalmente no que se refere ao processamento fonológico e ao desenvolvimento da consciência fonológica nos estágios iniciais do aprendizado (isto é, nas primeiras séries escolares), quando tais habilidades começam a ser desenvolvidas de forma sistemática. Conforme os estudiosos, os erros tendem a diminuir gradativamente com a escolaridade, sugerindo, assim, os prejuízos que podem ser causados pela evasão escolar, que acaba por interromper esse processo.

Nesse sentido, os resultados alcançados, aqui, foram comparados com os resultados encontrados em pesquisas (JOLY et al., 2009; ROSA et al., 2012; TENÓRIO; ÁVILA, 2012) que investigaram o desempenho escolar de estudantes das séries iniciais do ensino fundamental - etapa considerada adequada para a alfabetização. Com isso, foi possível perceber que o tipo de erro mais comum nesta população diz respeito à violação de formas dicionarizadas diferente, portanto, da encontrada entre alunos com defasagem idade/ano escolar. 
Zorzi e Ciasca (2008), também apontando essa categoria de erros - transgressão de formas dicionarizadas - como a mais frequente nas séries iniciais, justifica o resultado pelo fato de ser a etapa escolar em que as crianças costumam apresentar dificuldades em reconhecer que a grafia correta de algumas palavras pode ir além da compreensão de sua composição sonora, entrando em questões ortográficas mais complexas, como regras contextuais, gramaticais e/ou etimológicas. Essas dificuldades, segundo os autores, tendem a diminuir gradativamente, com a escolarização, visto que os alunos vão se apropriando das regras ortográficas e estabilizando a forma convencional de escrever as palavras; reforçando, assim, a hipótese da influência da escolaridade no processo de aquisição da escrita ortográfica.

Considerando-se, ainda, algumas pesquisas (ASSUNÇÃO et al., 2015; MOREIRA, 2018), cujos corpus e tipos de erros são semelhantes aos utilizados e alcançados neste estudo (alunos do 60 ano do ensino fundamental/erros apoiados na oralidade), além da utilização do mesmo tipo textual (narrativo) para a obtenção dos dados, é possível constatar que a quantidade de erros, referente à subcategoria mais recorrente, apresentada pelos três alunos pesquisados, aqui, superou em sete vezes a média apresentada pelos participantes das outras pesquisas. Ou seja, enquanto estes apresentaram média erros/alunos de 1,2 (relação de 99/80 e 34/28, respectivamente), aqueles atingiram o valor 8,6 (26/3).

Acredita-se, portanto, que o processo de alfabetização e letramento iniciado, por esses três indivíduos, nos primeiros anos do Ensino Fundamental ${ }^{8}$, tenha sido interrompido pela evasão escolar, vivenciada por eles, ocasionando, assim, o número elevado de erros encontrados em seus textos, bem como os tipos de fenômenos observados, principalmente os fono-ortográficos, como a neutralização (Ex.: "nu" ['nu] em vez de "no"), a monotongação (Ex.: "continuo" [kõtinu'o] no lugar de "continuou"), a ditongação (Ex.: "mais" ['majs] para "mas"), a força do padrão CV (Ex.: "bokiz" ['bokiz] em vez de "boxe") e o apagamento de coda silábica, especialmente do " $r$ " final em verbos no infinitivo (Ex.: "luta" [lu'ta] para "lutar") - fenômeno diagnosticado como o mais recorrente - , além de dificuldades no registro das sequências de algumas palavras (Ex.: "autima" [a'utfime] para "a última" e "si quer" ['si 'ke ] para "sequer").

Nesse sentido, de acordo com as teorias abordadas, supôs-se que a representação gráfica dos verbos infinitivos sem a letra " $r$ " final tenha sido armazenada na gramática mental desses alunos seguindo a estrutura silábica CV para a última sílaba, conforme a realização fonética da comunidade linguística da qual fazem parte. Assim, a escrita dos alunos parece refletir a forma como categorizam, na fala, o tipo silábico da última sílaba do verbo no infinitivo, considerando a posição de coda na sílaba e da classe morfológica (verbos), pois, em contextos de " $r$ " final em nomes ou sílaba interna, o registro da consoante aconteceu normalmente nos textos produzidos (Ex.: "esporte", "torneio" etc.), ratificando

\footnotetext{
8 Segundo Lemle (2000), dependendo do tipo de desvios lexicais encontrados na escrita de alunos de uma turma de 60 ano, é possível concluir que resultem de falhas no processo de alfabetização.
} 
Oliveira (1997), que aponta maior ausência do -r na posição de coda em verbos do que em nomes.

Além disso, acredita-se que o fato de a forma reduzida do infinitivo (fruto da interferência das características estruturais do dialeto dos alunos) ser usada na fala e possuir a mesma forma fonológica (sequência sonora) que a forma flexionada ( 3 a pessoa do singular do presente do indicativo), distinguindo-se apenas quanto à tonicidade (Ex.: "fala" [fa'la] = (ele) "fala" ['fale]), pode ter motivado os sujeitos da pesquisa a estabelecer diferentes conexões entre essas duas formas (reduzida do infinitivo e flexionada), sendo uma delas a morfofonológica parcial, representada na Figura 1, que utiliza o verbo "lutar" como exemplo:

Figura 1 - Conexão entre formas verbais reduzida do infinitivo e flexionada

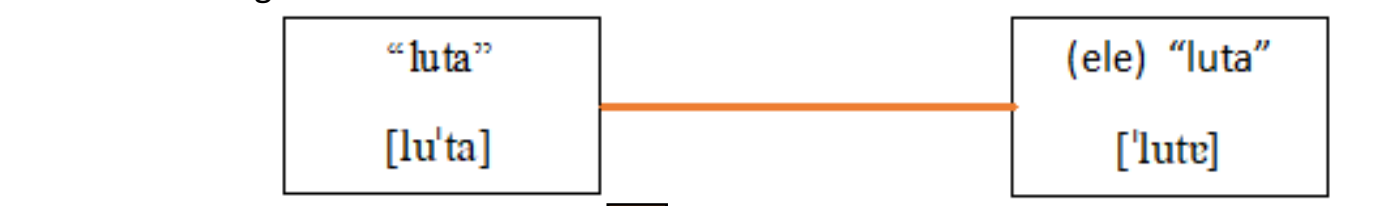

Legenda: Conexão morfofonológica parcial

Fonte: Souza (2018, p. 97).

A conexão morfofonológica parcial (linha laranja) representada acima - estabelecida entre a forma reduzida do infinitivo e a forma flexionada na $3 \underline{a}$ pessoa do singular do presente do indicativo - justifica-se por haver relação entre itens lexicais com significados gramaticais similares (verbos pertencentes a subcategorias distintas: reduzida do infinitivo e flexionada), cujas formas fonológicas são também similares, com identidade na sequência de segmentos sonoros, mas com diferentes tonicidades.

Por outro lado, ao considerar a produtividade da língua e os graus possíveis de similaridade entre seus itens, vale considerar que, no Português Brasileiro (PB), pode ocorrer, ainda, outro tipo de conexão morfofonológica parcial, no que tange à relação entre a forma reduzida do infinito (registrada pelos alunos sem o " $r$ " final) e a forma plena do infinitivo, conforme se vê na Figura 2, a seguir.

Figura 2 - Conexão entre a forma plena (existente no PB) e a reduzida (realizada pelos alunos) dos verbos no infinitivo

\begin{tabular}{|c|c|c|}
\hline "lutar" & "luta" \\
[lu'tah] & [lu'ta] \\
\hline
\end{tabular}

Legenda: Conexão morfofonológica parcial

Fonte: Souza (2018, p. 96). 
A Figura 2 indica que os itens lexicais de cada linha se referem a um mesmo exemplar constituído de duas unidades simbólicas (forma plena e forma reduzida, respectivamente), as quais se distinguem quanto à forma fonológica, mas se identificam quanto ao significado gramatical (ambos verbos infinitivos).

Assim como no caso da conexão morfofonológica parcial, a conexão fonológica total também pode aparecer, no PB, sob outra natureza conforme os graus de similaridade observados, por exemplo, entre nomes substantivos e verbos flexionados na 3 a pessoa do singular do presente do indicativo, ambos com padrão silábico CV e com identidade fonológica (tanto no nível segmental quanto na tonicidade), apesar de pertencerem a categorias morfológicas distintas. Esse caso é ilustrado na Figura 3, a seguir.

Figura 3 - Conexão entre o nome substantivo e o verbo flexionado

\begin{tabular}{|c|c|c|}
\hline (a) fala & & $\begin{array}{c}\text { (ele) "fala" } \\
\text { ['fale] }\end{array}$ \\
\cline { 2 - 2 } & ['fale] \\
\hline
\end{tabular}

Legenda: Conexão fonológica total

Fonte: Souza (2018, p. 98).

Comparando as Figuras 1, 2 e 3, foi possível deduzir que pode ter havido uma reestruturação silábica: de CVC (forma plena) passa a CV (forma reduzida), já que os alunos estariam focados apenas na identidade de segmentos sonoros, assumindo, nesse caso, a natureza da conexão fonológica total (linha azul).

Além disso, os alunos podem ter estabelecido também conexão entre o nome substantivo e a forma reduzida do infinitivo (produzida por eles), reduzindo o grau de similaridade entre os itens e gerando, assim, a conexão fonológica parcial (linha vermelha), já que, mesmo possuindo a mesma sequência de segmentos sonoros, os itens lexicais interrelacionados pertencem a categorias gramaticais diferentes (nome e verbo, respectivamente), além de formas fonológicas parcialmente similares, considerando as diferentes tonicidades. A Figura 4 ilustra, a seguir, a conexão supracitada.

Figura 4 - Conexão entre o nome substantivo e a forma verbal reduzida do infinitivo

\begin{tabular}{|c|c|c|}
\hline (a) fala & "fala" \\
['fale] & [fa'la] \\
\hline
\end{tabular}

Legenda: Conexão fonológica parcial

Fonte: Souza (2018, p. 99). 
Enfim, partindo do pressuposto de que "os itens lexicais armazenados na mente do falante são categorizados a partir de similaridades fonológicas e semânticas" (BYBEE, 2001, p. 109), gerando redes complexas de nuvens de exemplares, estabelecidas por semelhanças entre seus itens, pode-se explicar o favorecimento do fenômeno diagnosticado como o mais frequente na escrita dos alunos pesquisados.

Supõe-se que, na medida em que esses indivíduos tinham contato com os verbos no infinitivo (forma plena e forma reduzida), a partir do convívio com os outros membros das comunidades linguística e escolar das quais faziam parte, os itens lexicais em questão iam se agrupando em um sistema de redes de conexões, fazendo com que o fenômeno fonológico do apagamento do $/ \mathrm{r}$ / fosse se espalhado gradualmente através do uso frequente das formas já atingidas por ele, encorpando, assim, as nuvens de exemplares dos verbos no infinitivo, constituídos de uma só unidade simbólica (forma reduzida) na representação mental dos estudantes. Com isso, houve a transposição do fenômeno para a escrita, através da omissão da letra " $r$ " no final dos verbos no infinitivo, ocasionando um erro ortográfico ao conflitar com as formas verbais flexionadas na 3 a pessoa do singular do presente do indicativo.

\section{Considerações finais}

A realização desta pesquisa possibilitou a identificação dos principais erros ortográficos cometidos por 3 alunos do 60 ano do ensino fundamental, com defasagem escolar acentuada e em cumprimento de medida socioeducativa. Trata-se de dificuldades causadas pela interferência da oralidade na escrita, com destaque para o caso diagnosticado como o mais recorrente na escrita dos alunos: o apagamento do " $r$ " final em verbos no infinitivo, cuja natureza foi investigada a partir de uma análise à luz dos Modelos Baseados no Uso.

Assim, descobriu-se que a variação observada na fala dos alunos para o $/ \mathrm{r} / \mathrm{em}$ coda na sílaba final dos verbos no infinitivo estava representada no léxico mental deles, seguindo a realização fonética produzida pelos membros da comunidade linguística da qual faziam parte.

Além disso, o fato de, no dialeto ${ }^{9}$ dos alunos, a forma reduzida do infinitivo possuir a mesma sequência sonora que a forma flexionada ("lutar" [lu'ta] = (ele) "luta" ['lute]), distinguindo-se apenas quanto à tonicidade, pode ter ocasionado o estabelecimento de conexões com diferentes graus de relacionamento entre as formas analisadas (forma reduzida de infinitivo/forma flexionada; nome substantivo/forma flexionada; nome substantivo/forma reduzida de infinitivo), construindo um sistema de conexões a partir das similaridades entre esses itens lexicais.

\footnotetext{
${ }^{9}$ Dialeto do português brasileiro utilizado na região norte do estado de Minas Gerais.
} 
Dessa forma, concluiu-se que, apesar de haver, no PB, a conexão morfofonológica parcial entre as formas reduzida de infinitivo e flexionada, em razão de suas diferenças quanto à tonicidade e subcategoria verbal, os alunos estabeleciam a conexão fonológica total entre elas, visto que, mesmo considerando as diferentes subcategorias verbais envolvidas, eles não conseguiam perceber as diferenças de tonicidade existentes, focando apenas na identidade das sequências sonoras dos itens. Evidenciou-se, assim, o princípio gerador do erro ortográfico diagnosticado como o mais recorrente (o apagamento do " $r$ " final em verbos no infinitivo): a não percepção da diferença de tonicidade entre as formar reduzida de infinitivo e flexionada, refletida na escrita.

Com isso, foi possível pensar numa intervenção pedagógica realmente eficaz, porque pontual, no sentido de promover nos alunos a percepção de tal diferença de tonicidade e sua influência no cometimento do erro ortográfico em questão. Ou seja, era preciso conscientizar os alunos da existência de duas formas verbais diferentes (forma infinitiva e flexionada, com possibilidade de realizações fonéticas similares, mas diferentes quanto à tonicidade), exigindo, assim, o registro do morfema infinitivo para diferenciação uma da outra na escrita. Tal conscientização possibilitaria, portanto, uma reorganização das conexões estabelecidas no registro ortográfico do $-r$ final em verbos no infinitivo, ainda que a sua realização não fosse observada na oralidade.

Percebeu-se então a necessidade de uma proposta de intervenção com duas frentes de trabalho, paralelas e concomitantes: uma contemplando o desenvolvimento da consciência fonológica dos alunos, através de práticas lúdicas como a utilização de softwares; e outra, com atividades escritas reflexivas relacionadas às regularidades ortográficas morfológico-gramaticais, considerando o acento tônico e a estrutura silábica para o armazenamento do item com a presença do $-r$ final dos verbos no infinitivo, a fim de promover a percepção da inter-relação dos aspectos fonológico e morfológico envolvidos.

Além disso, era preciso fazer com que os alunos entendessem que, embora a realização fonética (sem a presença do $/ \mathrm{r} /$, conforme o dialeto ao qual pertencem) seja a forma reduzida (reconhecendo a legitimidade da variante linguística falada por eles), a sua transposição para a escrita (apócope) não deve ocorrer, posto existir um padrão normativo a ser seguido.

Por fim, ressalta-se a importância de se levar em conta a constante interação entre oralidade e escrita na construção da representação mental e na consolidação da consciência fonológica no sentido de enfrentar as dificuldades de natureza fono-ortográfica, tanto pelos alunos como pelos professores, já que não basta que os profissionais da educação saibam identificar o problema, é imprescindível que eles sejam capazes de desenvolver estratégias realmente eficazes. 


\section{Referências}

ASSUNÇÃO, M. A. L. et al. Análise de textos dos alunos do 6o ano: principais desvios fonológicos. Entrepalavras, Fortaleza, v. 5, n. 1, p. 117-139, 2015.

BARBOSA, L. P. O alçamento da vogal média anterior pretônica no português brasileiro: uma abordagem no Modelo de Redes. 2013. 220 f. Tese (Doutorado em Estudos Linguísticos) Faculdade de Letras, Universidade Federal de Minas Gerais, Belo Horizonte, 2013.

BARRERA, S. D.; MALUF, M. R. Consciência metalinguística e alfabetização: um estudo com crianças da primeira série do ensino fundamental. Psicologia: reflexão e crítica, Porto Alegre, v. 16, n. 3, p. 491-502, 2003. https://doi.org/10.1590/S0102-79722003000300008

BORTONI-RICARDO, S. M. Nós cheguemu na escola, e agora? Sociolinguística e Educação. São Paulo: Parábola Editorial, 2005.

BORTONI-RICARDO, S. M. O estatuto do erro na língua oral e na língua escrita. In: GORSKI, E. M.; COELHO, I. L. (Org). Sociolinguística e ensino: contribuições para a formação do professor de língua. Florianópolis: EDUFSC, 2006. p. 267-276.

BYBEE, J. Morphology: a study of the relation between meaning and form. Philadelphia: John Benjamins, 1985. https://doi.org/10.1075/tsl.9

BYBEE, J. Phonology and language use. Cambridge: Cambridge University Press, 2001. https://doi.org/10.1017/СB09780511612886

BYBEE, J. Frequency of use and the organization of language. New York: Oxford University Press, 2007. https://doi.org/10.1093/acprof:oso/9780195301571.001.0001

BYBEE, J. Língua, uso e cognição. Tradução: Maria Angélica Furtado da Cunha. São Paulo: Cortez, 2016.

CAGLIARI, L. C. Alfabetização e linguística. São Paulo: Scipione, 2009.

CAPOVILLA, A. G. S.; CAPOVILLA, F. C. Problemas de leitura e escrita: como identificar, prevenir e remediar numa abordagem fônica. São Paulo: Memnon, 2004.

DINIZ, N. L. B. Metalinguagem e alfabetização: efeitos de uma intervenção para recuperação de alunos com dificuldades na aprendizagem na linguagem escrita. 2008. Tese (Doutorado em Educação) - Universidade de São Paulo, São Paulo, 2008.

FERRARI, L. Introdução à linguística cognitiva. São Paulo: Contexto, 2014.

FERreiro, E.; Teberosky, A. Psicogênese da língua escrita. Porto Alegre: Artes Médicas, 1985.

GOMBERT, J. E. Atividades metalinguísticas e aprendizagem da leitura. In: MALUF, M. R. (Org.). Metalinguagem e aquisição da escrita - contribuições da pesquisa para a prática da alfabetização. São Paulo: Casa do Psicólogo, 2003. p. 19-63.

GOMES, C. A. Aquisição do tipo silábico $C V(r)$ no português brasileiro. Scripta, Belo Horizonte, v. 9, n. 18, p. 77-90, 2006.

GUIMARÃES, S. R. K. Dificuldades no desenvolvimento da lectoescrita: o papel das habilidades metalinguísticas. Psicologia: teoria e pesquisa, v. 19, n. 1, p. 33-45, 2003. https://doi.org/10.1590/S0102-37722003000100006 
JOLY, M. C. R. A.; BARROS, D. P. de; MARINI, J. A. da S. Dificuldades na escrita no ensino fundamental. Interação em Psicologia, Curitiba, v. 13, n. 2, p. 275-285, 2009. https://doi.org/10.5380/psi.v13i2.9799

LEMLE, M. Guia teórico do alfabetizador. São Paulo: Ática, 2000.

MOLLICA, M. C. Influência da fala na alfabetização. 2. ed. Rio de Janeiro: Tempo Brasileiro, 2016.

MOREIRA, F. P. Variação linguística, oralidade e desvios de ortografia em textos de alunos do 60 ano do ensino fundamental de Uberaba-MG. 2018. 177 f. Dissertação (Mestrado em Letras) - Programa de Pós-Graduação Mestrado Profissional em Letras, Universidade Federal do Triângulo Mineiro, Uberaba, 2018.

OLIVEIRA, M. A. de. Conhecimento linguístico e apropriação do sistema de escrita. Belo Horizonte: CEALE/FAE/UFMG, 2005.

OLIVEIRA, M. A. de; NASCIMENTO, M. do. Da análise de "erros" aos mecanismos envolvidos na aprendizagem da escrita. Educação em Revista, Belo Horizonte, n. 12, n. 1, p. 33-43, 1990.

ROSA, C. C. Rosa; GOMES, E.; PEDROSO, F. S. Aquisição do sistema ortográfico: desempenho na expressão escrita e classificação dos erros ortográficos. CEFAC, São Paulo, v. 14, n. 1, p. 39-45, 2012. https://doi.org/10.1590/S1516-18462011005000087

SEARA, I. C.; NUNES, V. G.; VOLCÃO, C. L. Fonética e fonologia do português brasileiro. São Paulo: Contexto, 2015.

SIMÕES, D. Considerações sobre a fala e a escrita: fonologia em nova chave. São Paulo: Parábola Editorial, 2006.

SOARES, M. Alfabetização: a questão dos métodos. São Paulo: Contexto, 2016.

SOUZA, A. de O. Consciência fonológica e ortografia: uma intervenção na escrita de alunos do ensino fundamental II. 2018. 141 f. Dissertação (Mestrado em Letras) - Programa de Mestrado Profissional em Letras, Universidade Estadual de Montes Claros, Montes Claros, 2018.

TENÓRIO, S. M. P. da C. P.; ÁVILA, C. R. B. de. Processamento fonológico de desempenho escolar nas séries iniciais do ensino fundamental. CEFAC, São Paulo, v. 14, n. 1, p. 30-38, 2012. https://doi.org/10.1590/S1516-18462011005000099

ZORZI, J. L. Aprender a escrever: a apropriação do sistema ortográfico. Porto Alegre: Artes Médicas, 2007.

ZORZI, J. L.; CIASCA, S. M. Caracterização dos erros ortográficos em crianças com transtornos de aprendizagem. CEFAC, São Paulo, v. 10, n.3, p. 321-331, 2008.

https://doi.org/10.1590/S1516-18462008000300007

Recebido em: 28/09/2019.

Aceito em: 02/03/2020. 


\begin{abstract}
ANEXOS
Seguem as versões digitadas dos manuscritos dos alunos e, na sequência, as cópias dos textos na íntegra. Os fenômenos identificados foram destacados na versão digitada para melhor visualização.

\section{Texto - Informante 1}

a menina de ouro

Era uma vez a menina de ouro que queria a luta Bokiz ela queria entra na cademia de Bokiz e ela trabalhava muito para entra cento dia ela foi testa luta ela não queria sai da cademia para aprende Fracki todo dia via ela mais nao queria ensina ela a luta e ele viu que ela tinha taleto e ensinou aluta ai ela aprendeu queria surbinu Rigriz e lutou e veceu a luta ai ela continuo a treina ai cento dia Fracki queria leva ela para luta e Las Vegas ai autima luta ela tava ganhando ai ela tomou uma pacada na cabesa e pedeu a memoria não cosiquenha mexe nada pedeu vou vimento e tava quase moredo e farki não quatava ver ela desse jeito apicou vacina nela e cabou moredo e frack ninguem mais via ele mais cabou sumido
\end{abstract}

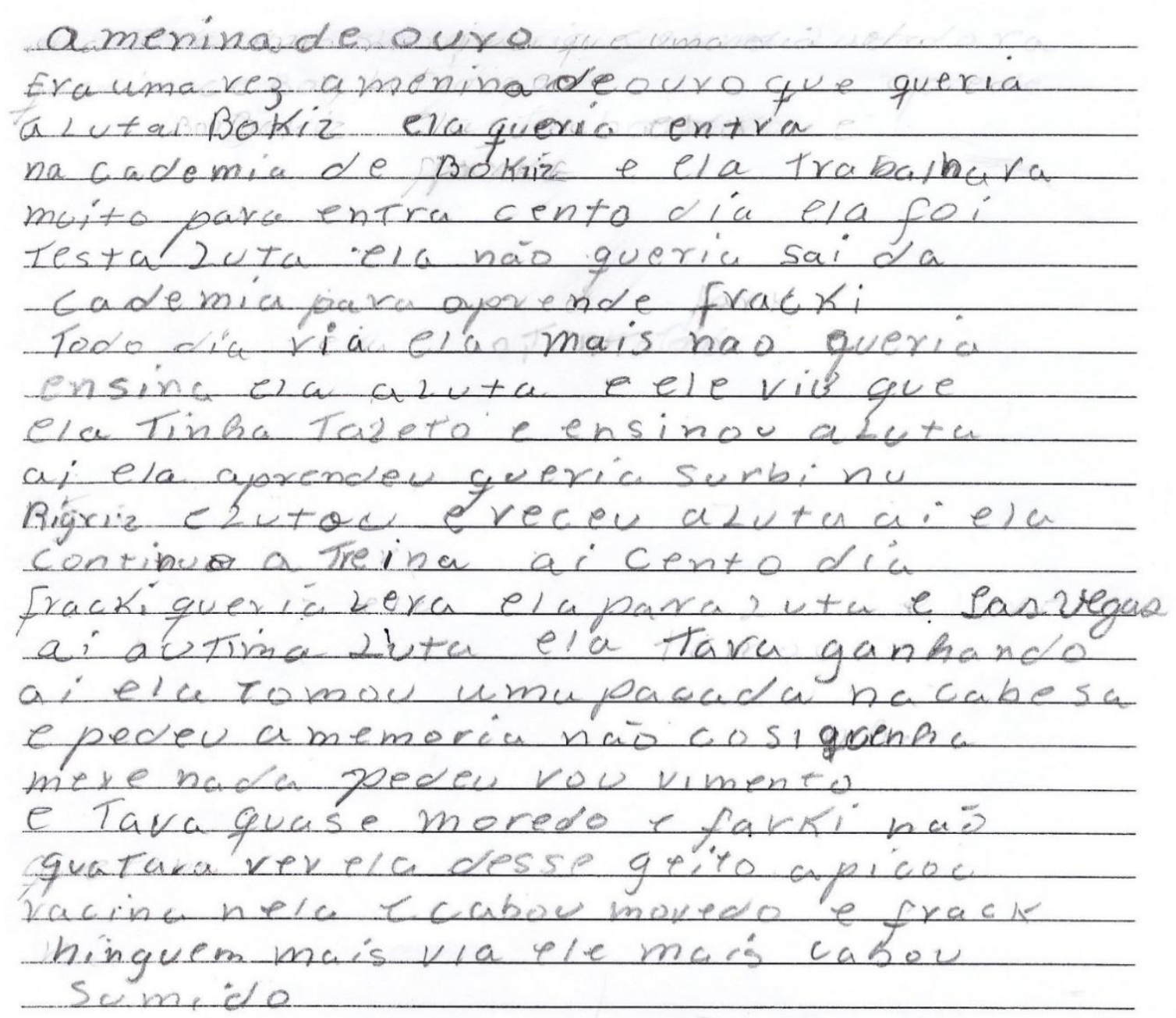




\section{Texto - Informante 2}

\section{A menina de outro}

Uma moça que um dia Viu um torneio de Boxe e se apaxonou pelo esporte e entrou numa academia para aprender o esporte mais por ser mulher sofreu muito preconseito mas teve um homem que teve pena dela e a ensinou o esporte com o tenpo foi aprendendo e praticando ai o dono da academia viu que ela tava ficando boa a treinou por três anos, ao passar do tenpo foi gostando dela por que ele a muito tenpo se desencontrou da sua filha e começou a cuidar dela como se fosse a sua filha, ai ela começou a lutar e se tornou a melhor lutadora e localtiava as suas oponentes no primeiro raude

E tinha uma campeam mundial chamada Bille Urso azul a desafiou ela a lutar pelo cinturão de ouro e por um milhão de dolares e no final da luta a Bille urso azul viu que ia perde a luta e trapasiou a derrubou e ela bateu a nuca no banco e ficou paraplegica, e não guentou o sofrinerto $e$ pediu o seu mestre para matala ai ele aplicou uma vascina na sua veia e ela morreu. Fim

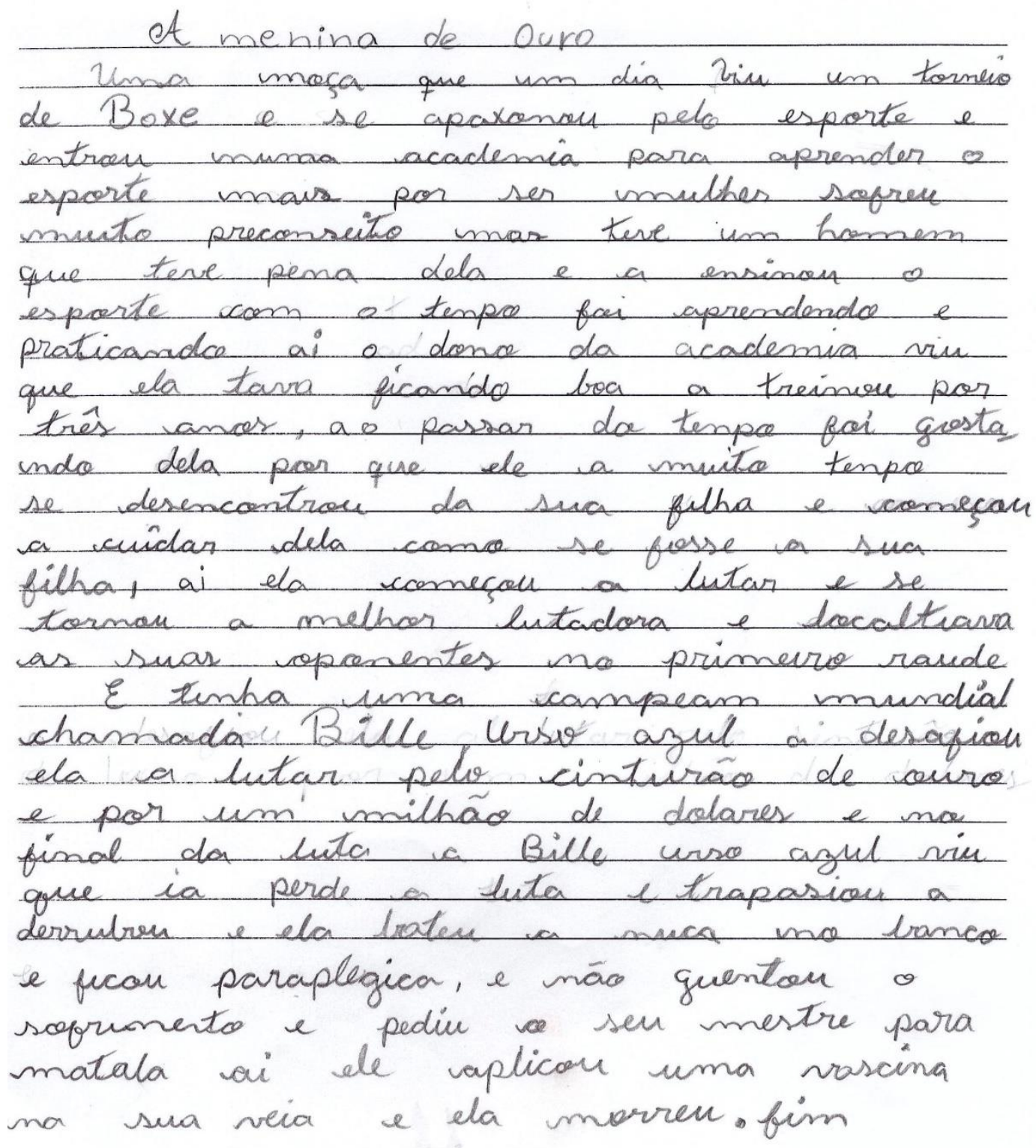




\section{Texto - Informante 3}

A menina de ouro: Tudo começa com um boxiador no começo ele estár lutando com outro boxiador os dois estár lutando até que em fim um vence a luta ai na outra parte tá passando uma mulher que tem 32 anos e já tem 3 anos que ela estar na academia e durante este 3 anos ela nunca teve um si quer chefe de academia até que um dia veio um velho que começo a treinar ela na academia de boxe e o sonho dela e ter uma luta até que um dia o chefe dela arruma uma luta pra ela e nesta luta ela vence muitas coisas tipo muitas lutas ai ela começa a ganhar dinheiro até que ela conprou uma casa nova pra mãe dela e a mãe fala que vai tentar ficar com a casa ai na utima luta que ela teve aconteceu um acidente que outra boxiadoura trapaciou e ela caiu de cabeça ne uma cadeira e ficou em coma ai a mãe dela foi no hospital pra so pra pegar a erança que ela tinha mais ela não passo ela resolvel e pediu o chefe dela pra desliga a maquina de respiratorio ele não aceito mais até que um dia ele resolveu e foi e desligo a maquina e ela dormi. FIM

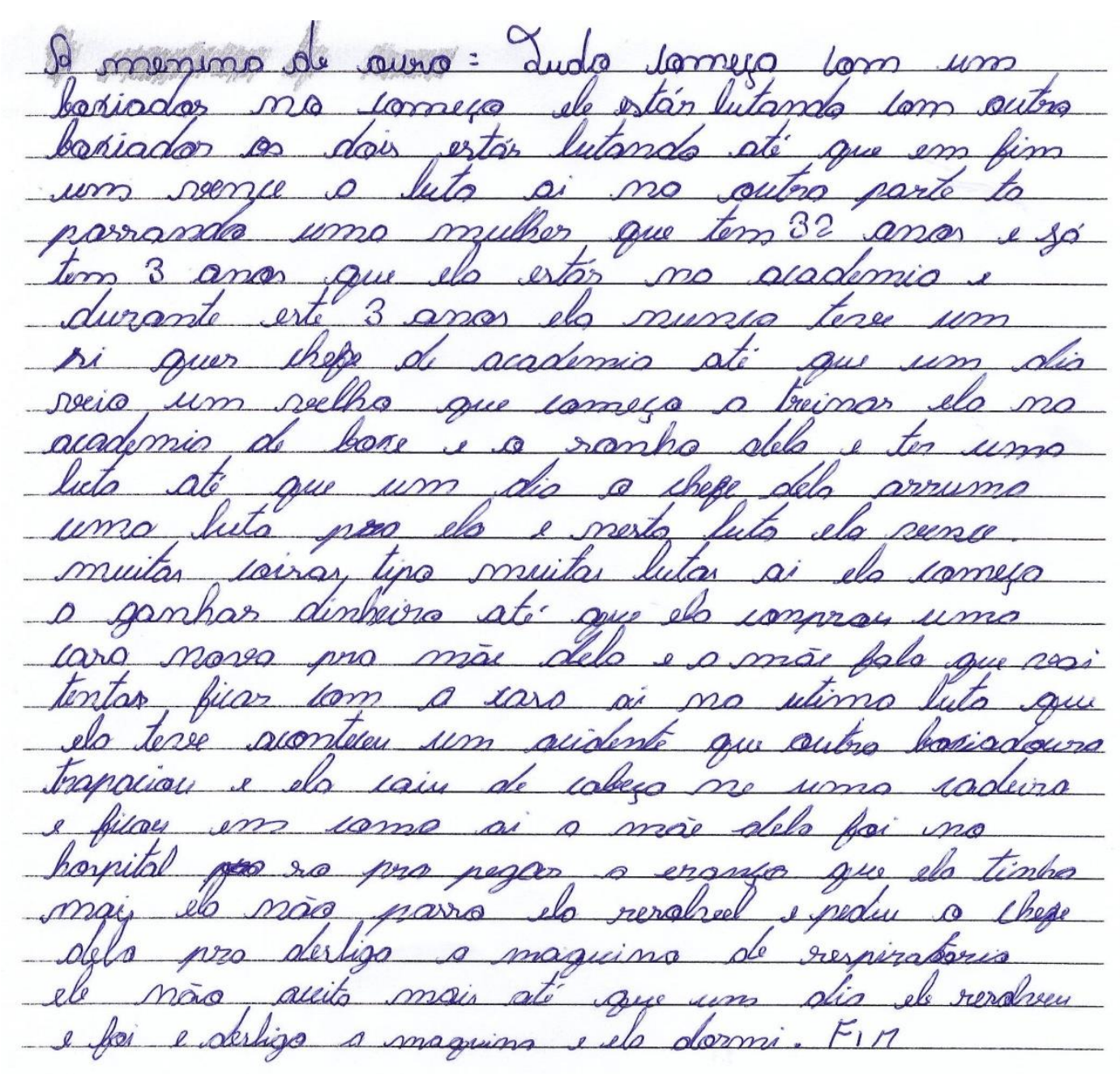

